\title{
Before and beyond Brexit: political dimensions of UK lifestyle migration
}

\author{
Jeremy MacClancy
}

\begin{abstract}
Lifestyle migration is a now-established section within the anthropology of migration, and interdisciplinary migration studies, usually justified by its extensive and increasing spread, globally. Yet, bar a few exceptions, the political behaviour of lifestyle migrants has been relatively neglected. I redress this imbalance by critically comparing two overlapping processes where British migrants to Spain act politically: elected councillors in town-halls; campaigning anti-Brexit activists. This pair is as comparable as it is contrastive. In theoretical terms, I argue that modern versions of practice theory are a useful mode for analysing municipal activity by foreign agents, while the Brexit process, because novel, fast-paced, and open-ended, is better understood via Isin's 'enactment of citizenship' approach. Both explanatory modes are powerful, have perspectival slants, and are best applied to different contexts and styles of contest: practice theorists research how people work with change; Isinians, how they produce it. The paper also furthers the anthropology of citizenship by investigating a case where the link between citizenship of a country as a prerequisite for legitimate political activity in it is broken.
\end{abstract}

Lifestyle migration is now established within interdisciplinary migration studies, usually justified by its extensive and increasing spread, globally, and defined as 'relatively affluent individuals, moving either part-time or full-time, permanently or temporarily, to places which, for various reasons, signify for the migrants something loosely defined as quality of life' (Benson and O'Reilly 2009a: 621; 2009b). These studies cover a range: downsizers, premature retirees, pensioners, labour migrants. Their research foci usually encompass the decision to migrate, its practice, identity, the search for a better way of life, the process of settlement, and relations with locals (e.g. Benson 2011; O'Reilly 2012). Yet, bar a few 
exceptions (e.g. Janoschka 2009; Collinson 2015; MacClancy 2015), the political behaviour lifestyle migrants may perform has been relatively neglected (Janoschka \& Durán 2014: 61).i It is as though the lifestyle the migrants seek were an apolitical one which excludes the possibility of engaging with power, especially with institutions of the state, at a variety of different levels. As one overview of migration and social change states, the role of migration is 'to buttress existing structures of power rather than challenge them' (Portes 2010: 1549). The theoretical discussion and ethnographic material I present questions that claim.

Here I address political dimensions of migration, assessing alternative ways of studying migrants' political activities. Thus I discuss and compare two overlapping processes where British migrants to southeast Spain engage in political behaviour: elected councillors in town-halls, and campaigning anti-Brexit activists. This pair is as comparable as it is contrastive. In theoretical terms, I argue that while contemporary practice theory might be a useful mode for analysing municipal activity by foreign councillors, the Brexit process, which is quite different in nature, is better understood in terms of Engin Isin's concept of the 'enactment of citizenship' (Isin 2008: 15). My aim is to suggest which approach is best suited to which contexts, and so to both develop the political dimensions of the anthropology of migration, and lifestyle migration studies, and further the investigation of political citizenship. For if there is no single theory adequate to explain migration in general, different theoretical approaches being applied in different contexts (Bakewell 2010: 1692), I argue similar statements can be made of a particular sub-field: lifestyle migration studies.

'Brexit', as used in the media and popular parlance, is a usefully vague term. It can refer to (1) the referendum of 23 June 2016 about departure of the UK from the EU; (2) the exit itself, at present (at time of writing) set for 11pm 29 March 2019; (3) the expansive political process caused by the result of the referendum. Since I am concerned with the various ways British migrants talk of Brexit, I follow their use of the term in all three senses.

Brexit may be regarded as but another example of the restructuring of European politics stimulated by the 2008 debt crisis (e.g. Theodossopoulos 2013; Franquesa 2016). I wish to join with these authors, who broach 'indignation' as a comparative concept, highlighting the affective dimension of political activity. Further, there is already commentary by anthropologists on several dimensions of Brexit itself, e.g. contributions to Green 2016; Edwards, Haugerud, \& Parikh 2017. But much of these writings, however illuminating, are prompt reactions to the recent events, rather than fieldwork-based analyses. Also, none are concerned with the millions of British abroad, within the EU. To these extents, supplementary aims of this paper are to develop the study of contemporary political subjectivities, and to make an innovative, early ethnographic contribution to what, we can expect, will be a continuing topic of anthropological investigation.

I have been conducting fieldwork in Alicante province since 2005. For the first ten years, I undertook ethnographic fieldwork for two months each year. In 2015 I focussed this research when a geographer of migration, Fiona Ferbrache, and I agreed to study 
comparatively political activity of Briton residents: she in southwest France, me in Alicante province. The analysis presented in this article is based on my long-term fieldwork as well as interviews with over 25 people, some several times, between 2015 and 2017: practising or former British councillors, their Spanish opponents, their compatriot acquaintance; British consular officials; a Liberal Democrat MEP; British office-holders in local political and socially-oriented organisations. April and June 2017 Ferbrache and I staged meetings in Elche, province of Alicante, and Perigiuex respectively, on Brexit and British migrants, attended by campaign group representatives, consular staff, British residents, social scientists, local politicians, and the press. At these meetings campaign group representatives and British consular staff spoke to an audience of British residents, social scientists, local politicians, and the press. After the Elche meeting, I interviewed several participants and other campaign leaders. I also traced the activity of some former British councillors via digital archives of the local press.ii My contact with members of the antiBrexit groups: I have interviewed several members of these campaign groups, some more than once. Though I have been invited to participate in their gatherings, and their demonstrations, I have declined. My relations with them may thus be classed as friendly and highly informative, but I do not get internally involved.

In the sections which follow, I start with a comparative account and assessment of modern practice theory and Isin's approach, followed by two ethnographic analyses: who, among British migrants to Alicante province, Spain, become town-councillors, why, and to what effect; the emergence of anti-Brexit campaign groups in Spain, who lead them, what they aim for politically, how they operate. I then compare the different discourses employed by participants in both arenas. The concluding section critically assesses the power of practice theory and Isin's approach to these twin, but different political process. The broader aims of this paper are (1) to contribute to our critical understanding of the anthropology of political agency, with respect both to established but evolving systems, and to rapidly transforming, open-ended processes; (2) to further the anthropology of citizenship by investigating a case where the link between citizenship of a country as a prerequisite for legitimate political activity in it is broken.

\section{Approaches to political activity}

Some of the theoretically most sophisticated approaches to lifestyle migration have been inspired by Bourdieu's theory of practice (e.g. Bourdieu 1977; Bousiou 2008; Janoschka 2009, 2011; O'Reilly 2012; Lawson 2016). For these authors, Bourdieu's work is valuable because it can integrate micro and macro levels of analysis; attempts, via his concept of habitus, to transcend dualisms of structure and agency, materialism and idealism; and deploys a fine-grained approach towards the investigation of social class and its sub- 
sections. For example, Oliver and O'Reilly show how migrants might move in order 'to start a new life' only to find that non-economic forms of capital come to loom large and divide the incomers according to other resources (Oliver and O'Reilly 2010). Also, the 'clean' break with their British past which many migrants claim to desire turns out in fact to be constrained by their habitus. It is not so much that they cannot realise their dreams rather, the constitution of their dreams is part of the past they wished to leave behind. 'In other words, their relative symbolic capital (incorporating educational, cultural, and social capital) impacts on the decision to migrate and the destinations chosen, but also the life then led in the destination' (Benson and O'Reilly 2009a : 618).

Bourdieu's approach can be criticised for its 'ethnocentric' conceptions of social class, elitist modes of distinction, and other univerisalising notions, while his focus on reproduction of social forms is claimed to leave little room for change (Jenkins 1992; Bousiou 2008: 22; Beigel 2009: 20-21; Gemperle 2009: 14; Woodward and Emmison 2009: 2; Daloz 2013). In response, Bourdieu claimed that he had intended habitus as a generative structure, albeit one whose generative capacity is limited by conditions of the time and place of its production (Bourdieu 1990). Thus, his later elaborated idea of habitus can be made to accommodate 'invention and improvisation, such as lifestyle projects' (Benson and O’Reilly 2009: 617).

Contemporary practice theorists, building on Bourdieu's work while fully acknowledging its limits, seek to overcome some of the above difficulties and broach more centrally the analysis of change. Mouzelis calls for the need to recognise both intra-habitus tensions and interaction between actors in a field (Mouzelis 2007). Kemp argues that habitus needs to be integrated with reflexivity, to provide scope for individual agency (Kemp 2010). O'Reilly, a leading exponent of modern practice theory, attempts to synthesise many of these corrective elements in a broad overarching approach to migration studies, which strives to take account of external structures, internal structures (including habitus), communities of practice, and outcomes. Of habitus she states that it is both 'fairly fixed and transposable', and 'constantly changing and adapting', though she does not detail the relation between fixture and change (O'Reilly 2010: 151, 160). While her synthetic approach to practice theory is broadly encompassing, she recognises it 'merely provides the meta-theoretical frame within which disparate studies can be brought together. It does not attempt to do all the work that other theories and concepts contribute' (O'Reilly 2012: 84). She affirms her 'careful and critical' eclectic style of practice theory should 'not be applied too rigorously': it is, after all, a heuristic framework (O'Reilly 2012: 7, 160). Postill argues in a parallel manner, that practice theory 'cannot be a theoretical cure-all'; e.g. it cannot tackle a 'world-historical moment', such as the Danish Muhammed cartoons controversy, caused by the September 2015 publication in a Danish newspaper of cartoons depicting Mohammed, which he considers more a political process than a social practice (Postill 2010: 12-13). Comparable comments could be made about Brexit: it is above all an extended 
process, and the anti-Brexit campaign is not a set practice, but an innovative part of that process.

For Swartz, Bourdieu expected everyday disalignment between habitus and particular fields: mild disjuncture leads to adaptation, a gradual modification of structures; considerable disjuncture to transformation, producing resignation or revolt. Yet how these protests can lead to change is left unsaid: Bourdieu did not develop a politics of habitus (Swartz 2013: 236-41). Swartz's concerns are bared in the illuminating work of modern practice theorist Michael Janoschka, who like me, worked in Alicante province, and on politically active migrants: the mid-2000s successful campaigners against massexpropriation programmes in the Valencian Community (which includes Alicante); they were protesting against local politicians' abuse of legislation in order to urbanise private land and charge the landowners for doing so.iii Janoschka recognises practice theory, 'developed in and exemplified by a virtually pre-modern society, . . . has certain shortcomings if the mobile conditions of people, capital, knowledge and practices in late modernity are reckoned' (Janoschka 2011: 228; also Kemp 2010: 156). However, 'a rapid and shock-like transformation' can 'produce a field of critical attitude that requires new interpretations and incorporations of the social world' (ibid.: 228). Thus, threatened incomers in Valencia established 'a temporarily radicalized habitus', on a par with Bourdieu's late invention of a 'subversive habitus' (ibid.: 234; Bourdieu 2005). But Janoschka declares he cannot tell if the consciousness of the usual habitus dispositions endures and 'the weight of the reified world is still felt', or if a prolongation of the crisis turns the provisionally radicalized habitus into a permanently reconstituted one (ibid.: 229). I suggest an empirical answer to his dilemma, below.

Janoschka's response to the challenges of his fieldsite is imaginative but he makes habitus do too much work. He stretches it into a catch-all concept so malleable nothing can escape its reach. This version of praxis puts it on a logical par with Darwinianism: all examples, no matter how seemingly aberrant, can be made to fit into its theoretical schema. In sum, when powerful external forces, on the very margins of the quotidian habitus, stimulate a diversity of creative responses in people trying to imagine, and to influence their place in an open-ended future, then expanded versions of the concept of habitus are stretched to new levels of elasticity, with all the tensions that entails. The relative inertia of habitus, unless defined in O'Reilly's terms, is not easy to reconcile with the consideration of radical, lasting alteration. At the very least, just as a Darwinian framework forces one to think in terms of evolution, so deployment of habitus reminds us that dispositions are not wholly individual but structured; perhaps malleable but not completely open to fundamental change. Given this orientation of habitus towards more stable dispositions, it seems advisable, when studying fast-moving processes of significant change, such as Brexit, to look elsewhere, for instance to the work of Engin Isin on politics within Europe. 
This is not to be antagonistic to contemporary practice theory. When it is pitched at such a high level as O'Reilly's informative approach, it is complementary to, not conflictive with alternative theories, e.g. Isin's. Here the question is, which explanatory frameworks are the most suitable when accounting for gradual change or for abrupt alteration. Which is the more telling, for each context?

In his evolving work on citizenship in Europe, Isin is not concerned with social reproduction but with social emergence (Isin 2008). For that reason, he wishes to avoid the downsides of conventional modes of thought in the political sciences, which otherwise threaten to confine new configurations of social process within traditional taxa. He wants to catch, and follow the provisional, fluid nature of challenging processes in a vocabulary unfettered by the confining connotations of established terms, developed in times of different circumstances, when nation states seemed sovereign and groups clearly defined.

To free himself from those tired vocabularies, Isin devises a novel nomenclature and procedures for studying what he terms 'acts of citizenship' (Isin 2013: 21-8). This is an activist-centred approach, which does not concentrate on rights as legal rules upheld by authoritative bodies integral to the nation-state or supra-national body, particularly the EU. Isin sees citizenship as much a bundle of legal rights as 'a social process through which individuals and social groups engage in claiming, expanding or losing rights' (Isin and Turner 2002: 4). Thus, his emphasis tends towards the study of norms, practices, meanings, and identities, than on legal rights.

Rather than researching even relatively stable social states, Isin focuses on unfolding, future-oriented, exploratory, contested processes, which at the same time form its activist protagonists into groups. For him there is no fixed EU polity, rather a complex European juridico-political space, composed of elements and arrangements, i.e. the legal and constitutional foundations of citizenship, which are sometimes contradictory, sometimes complementary. Citizenship here is not a stable category, but contingent, dynamic. Subjects make claims to rights, which invoke and challenge the arrangements within the broad assemblage of European institutions. Claimants traverse different sites and scale of rights which may cross a range of these institutions, and may do so in an unorthodox manner which confronts 'dominant understandings of citizenship as membership in a contained polity' (Isin and Saward 2013: 15). Coming together as common claimants, transcending boundaries as they go, generates new sites of belonging and identification. Sites and scales are not pre-fixed, but fluid, relational; they are formed through contest. Thus Isin's 'enactments of citizenship' are performative acts which produce subjects who collectively challenge present configurations, and which start to take what they ask for. Rights are not top-down exercises in abstract legalese, but here take on a social reality because they are claimed, usually bottom-up (MacClancy 2000: 118), by those whose performance of claimseeking constitutes them as political actors. This is a theoretical approach empirically focused on change and the conflicts which go with it, which examines topics previously 
confined to the legal, in a variety of interconnected dimensions: political, ethical, cultural, sexual, and social (Isin 2013: 41). In particular, it is a shift from conventional rights-based studies, grounded on black-letter law, to ones more focused on processual, political dimensions.

Isin is explicit about the distance of his approach from Bourdieu and his followers. Practice theory attends to social formation, Isin to its reformation; practice theory focuses on subjects who conduct themselves, Isin on subjects who act (Isin 2012: 108-9). He recognises practice theorists, to their credit, have demonstrated the role within citizenship of habitus 'formed over a relatively long period of time': but 'the question of how subjects become claimants ... within a relatively short period of time has remained unexplored' (Isin 2008: 17). For Isin, acts stand in contrast to habitus. Habitus emphasizes relatively enduring dispositions and accounts for 'the persistence of an order'; acts are purposive, performative ruptures, which create disturbance. These ruptures enable actors (created by the acts) 'to create a scene rather than follow a script' (Isin 2009: 379). Thus for Isin, here moving beyond practice theory, 'to be a citizen is to make claims to justice, to break habitus' (ibid.: 384).

A further contrast between these two approaches is scale. Practice theory is allencompassing in scope, seeking to knit meso- and micro-level events with macro-level social structures (e.g. globalisation), which individuals have relatively little ability to control or manipulate. We might call Isin's aims more demographically modest. He is not trying to explain whole societies. While including macro-level dimensions within the complex contexts of his localised case-studies, he concentrates on activist attacks to structure rather than the structures themselves, however enduring or adaptable they might be, i.e. if he pushes structure out of the foreground, he replaces it with actors who enact.

\section{Brits abroad, in town-halls}

In this, and the following section, I provide concentrated ethnographic accounts of (1) the lived experience of British residents who became town-councillors, and (2) the emergence and organisation of anti-Brexit groups by Britons resident on the Continent, above all in Levantine Spain. These two sections enable the subsequent ones: a comparison of the discourses of the British town-councillors and of anti-Brexit campaigners; and a critical assessment of the two theoretical approaches, contemporary practice theory and Isin's.

Mass tourism in the early 1950s brought rapidly increasing numbers of Britons to holiday in Alicante. Some bought summer homes; some of them went on to live there fulltime. Benidorm, a fishing village, turned into the greatest conglomeration of high-rise buildings per capita in the world. Construction became the largest Alicantine industry, with 
large housing estates created for the migrant market. Indigenous society experienced profound transformations, deeper and more broadly than in most other parts of Spain. New sources of wealth generated widespread affluence alongside new forms of social division.

In 1999, for the first time, residents from other EU countries were for allowed to vote and stand for office in Spanish municipal elections. By 2007 in Alicante three dozen, the majority of them British, had seats on town councils. These British councillors are strikingly diverse: in background, political trajectory, and degree of success. All but one had at least a full secondary education, a few were graduates. In the UK they had held various positions: company secretary, accountant, restaurant owner, etc., with a disproportionate representation of ex-policemen. Most councillors were at least late middle-aged. None had participated in party-based political activity in Britain, though close kin of two had been councillors or mayor back home. All already had some public presence, sometimes in the UK, more often since migration. In Spain, several had won local reputations as energetic activists who boosted charitable organisations, or organised campaigns, for migrant or environmentalist interests; one had set up Citizens Advice Services, weekly in a bar, where he was also approached for personal advice on a range of issues.

Their experience of office is very mixed. Several felt marginalised, by fellow members of the local party and within the council, both in municipal matters and linguistically. One felt her successful efforts to raise party affiliation among migrants was then undermined: other councillors for her party feared she' $d$ use the boost in numbers to form a migrant faction bent on unseating them. One, interviewed by a resident British journalist in 2003, stated she faced open xenophobia from another councillor, who thought 'the result of letting such people into the town hall is the destruction of local culture'. The latter councillor added, 'It means changing the way we lived. People call me racist but I ask the foreigners whether they would like it if a Turk was running the town-hall where they come from, and most agree with me' (in Tremlett 2003).iv Local journalists may portray British residents in distanced, amused terms (e.g. Valdés 2015), but this councillor's comments were a rare public display of unapologetic xenophobia.

If within the governing group, the incomers were usually given the brief of representing European migrants within the area, but felt excluded from other business. They considered they were left with specific council business they had expertise in and which did not interest fellow councillors. Anything else on the municipal agenda was usually kept from them by non-migrant members of the governing group: 'Things always happened without my knowledge or consultation. "Oh sorry! An oversight", they would say. But it happened too often to be only an oversight.' One councillor, who had got his initiatives implemented, said, 'They were initiatives I was allowed to do to keep me from asking too many questions.' Other initiatives of his had been rejected as they 'would have been good for my reputation'; he felt the governing party did not want him too popular. He thought they regarded him as 'a nuisance, and often a thorn in their sides, because I wanted to 
change things.' According to another British councillor, 'I do not think any of the Spanish councillors were $100 \%$ happy that they had foreign councillors, there are three of us (one British, one German, one Belgian), but realised it was necessary.' In general, these Britons felt they were being exploited for their electoral support from, plus access to and knowledge of a particular municipal population. They were not invited to ponder other matters. From their point of view, they were being used, and contained.

In contrast several considered they had managed to work well with fellow councillors, whether native or migrant, and had achieved much while in office. They were no longer merely a bridge between the town-hall and the people they assisted; now in the town-hall they could strive to secure reform. Some listed initiatives they had fomented and seen implemented, successfully: researching and putting into action a municipal version of the UN Agenda 21 for self-government; applying for multi-million euro EU grants; revamping their town's tourist strategy; running a range of health campaigns; setting up a charitable network to assist the needy; developing town-hall/migrant relations; integrating the socially isolated; winning national awards for mobility strategies; and so on.

At the time of standing, all of the British councillors spoke Spanish at least moderately well; in contrast, some other non-Spanish councillors in Alicante do not gain a command of the language, even while in office. Two British councillors stated native councillors excluded them in meetings by speaking Valencian. Both learnt to understand Valencian. The councillor who works with German and Belgian counterparts said they spoke English to one another, i.e., in some municipalities, council business is now being pushed towards the polyglot (English, Spanish, Spanglish, Valencian, Vanish [Valencian-andSpanish]), with basic Spanish as lingua franca.

British candidates stood for a range of parties, with a slight majority on the centreright. In one municipality, a British woman had stood for the centre-right: in reaction her brother formed his own party, to oppose her: both were elected (Tremlett 2003). Whatever their allegiance, these councillors talked of national parties in strongly local terms. The municipal chapter was their primary loyalty, its regional branch viewed as occasionally overbearing and self-interested. They seemed more interested in municipal personalities than to party stances or national policies. Thus several had changed parties, more than once, justifying their switches by moral assessment of the representatives involved at that time, e.g., one environmental activist started in the Greens, which amalgamated with a leftwing party; they conjointly entered into a coalition with the centre-left. Later they left the coalition and joined a successful motion of no confidence. They then entered a coalition with the centre-right, so winning control of the town-hall. At the following elections the activist was elected for the centre-right. Her actions are not particularly unusual, whether among foreign resident or local representatives. For each transition, she explained her actions in local, not national terms: some were corrupt, she claimed; councillors affiliated to one party, now with charges brought against them, had been replaced by a 'new team, 
people I could trust'. Generally in Alicantine politics, indigenous membership of parties can be very unstable. Transfugas ('defectors, turncoats') switching party is a much-denigrated, much-practised strategy.v

Migrants also stand as independents or form their own parties (Simó-Noguera et al. 2005: 20-21). One said he had approached local branches of national parties, only to be rejected: from his point of view, they did not want those they regarded as outsiders. He and fellow migrants formed their own political party, though administrators made their official recognition very difficult throughout this bureaucratic process. In 2010 they finally established Partido Independiente por las Nacionalidades (PIPN). At its height, its representatives were elected to two of the thirteen councillorships in its local town-hall, while its busy Facebook page demonstrates its sustained raft of activities and campaigning, as well as the space given in the regional press to its campaigns. Some party members called for secession of the large, migrant-dominated estate: electorally, it dwarves the original village yet receives a disproportionally low fraction of the municipal budget to fund services. They wish the estate to constitute its own municipality, receiving its resident's taxed income rather than losing it to the village town-hall. This municipal rebordering, primarily for fiscal purposes, is a long-established practice in Spain. Migrants' deployment of this strategy is a further example of their adaption to their new place of residence.

Most foreign councillors were surprised by the deeply politicized conduct of municipal business, with accusations of corruption or favouritism embittering town-hall debates. Some were taken aback how easily partisan interests smothered communal concerns. But since none had direct party-political experience in the UK, their surprise lacked comparative base. Some complained of vote-rigging: they claimed the registration of some migrant residents 'dropped off the register', and supporters of the mayor's party were allowed to vote though unregistered. Some described the style of some mayors as ademocratic, even edging towards the dictatorial. One said the mayor came to his house, and banged the table: 'This is how things are! This is how things will be!' November 2017 the mayor was found guilty of prevarication and banned from holding public office for 8 and a half years.

'Corruption' was a much-repeated concern of British councillors. Since its perceived scale is an evolving composite of political, judicial, economic, and media factors, I cannot here report on its incidence, only report its perceived prevalence. Alicantine sociologists argue that over the last thirty years the devolution of powers from higher to municipal levels of government has enabled corruption to spread (Huete and Mantecón 2012: 91). One British councillor stated that in the 2011 elections, the till-then governing party and the opposition forces won four seats apiece, making him 'the key', i.e. that his support would open the door to the town-hall for either faction. Shortly after, he said one telephone-caller offered him a car, and another suggested, 'Go with us, and by the end of your term, you'll be a millionaire.' Or, as the (Spanish) President of his Residents' Association put it to me, 
'There is no honest political class in Spain. People get elected to make money.' Further, in October 2008 in San Fulgencio municipality, the sole British councillor became the default leader of the town-hall after the mayor, deputy mayor and four other councillors were 'taken into police custody following allegations of real estate corruption'; he spoke a 'smattering' of Spanish (Govan 2008). In turn, some British councillors have been formally accused of corruption by the appropriate legal bodies. One ex-councillor accused of this explained that he had resigned so that any of his planned, further municipal actions could not be questioned, and to reinforce his point that the mayor, already facing multiple charges, should himself have stepped down long before.

Nepotism was a further concern expressed by British councillors. Two councillors from one municipality said all eight members of the governing body in their town-hall are close kin or affines, with municipal contracts going to their relations, in-laws, and friends, in a stereotypical clientelist manner: in their view, large contracts are rapidly waved through meetings, and smaller contracts can lead to surprisingly large bills. Throughout Alicante province, the continuing succession of court cases against municipal corruption, widely reported in the local press, suggest why these practices are perceived as widespread.vi According to one British ex-councillor,

I have witnessed so much corruption here that some politicians treat it as a hobby. Some councillors treat the Council workforce as their own and get them to do their gardens, paint their houses, etc. The workers say nothing for fear of losing their jobs. Politics in Spain is dirty. It needs to be cleaned out.

The Alicantine sociologists refer to a 'deficit in the quality of local democracy' (Huete and Mantecón 2012: 89).

Anthropologists of Europe speak of small-town inhabitants forming 'moral communities' (e.g. Heiberg 1989; Sorge 2009). We may be observing much the same in the context of Spain. As British consular staff underlined, 'There is a large "grey area" between what is illegal and what enchufismo ("plugging-in"), i.e. helping your family and friends get jobs and make money'. What is regarded as corruption appears accepted, so long as it is kept within bounds. British migrants repeatedly told me most locals, though friendly, still regard them as 'fair game'. Data from my own fieldwork suggest migrants are not singled out: several resident British migrants said to me that any outsider from beyond the locale may be taken advantage of. Spanish (social scientist) colleagues of mine based in the general area did not deny it, just downplayed its incidence, i.e., these moral communities usually exclude others, whether from other lands or provinces; and when assessing municipal actions, locals live in a constant tension between state-defined legal codes and what they will accept as tolerable practice.

In my discussions with British councillors and municipal activists, complaints about corruption, nepotism, and local forms of democracy segued with moral assessments 
grounded on 'fairness' and 'justice'. The secretary of one residents association said, 'I'm not going to stand for office. I just want things for the people here.' The councillor who set up Citizens Advice Services said he had done so, 'Because I'm a mean Scotsman', who thought local service providers overly greedy, 'just taking money from the expats. This is unfair. Lots of things are unfair in this world, and I'd like to rebalance it.' The PIPN Facebook page speaks of making 'creative and meaningful steps towards political empowerment of the expat community.' Guided by their 'moral and ethical concerns, our intellectual contributions and our strength of numbers', they 'want to help to give our community the voice it needs and deserves.' vii Its founding President told me its ethos was 'fairness, equality, openness for all the residents of the municipality' (original emphasis).

The practice of British migrant councillors need not develop in this way, as the little comparative material available suggests. Studies of British councillors in France show they stood for election primarily for social reasons: to expand their acquaintance and get involved in local projects (Ferbrache and Yarwood 2015). Indeed several councillors were so disinterested in political process that, when interviewed in 2007, it became clear how poorly they understood the French political system. One could not even name the current prime minister (Drake and Collard 2008: 227). In sum, the diverse, energetic Britons elected into town-halls had mixed experience of office: of achievements and frustrations. Their actions were limited to the municipal, and their evaluatory discourse grounded on general notions of 'fairness' and 'justice'.

\section{Brits abroad and Brexit}

In this section, I summarise the rise, composition, organisation, aims, and apparent effectiveness of the anti-Brexit groups in Alicante province. This, together with the preceding section, allow us to compare, in later sections, differing modes of political behaviour among British residents in Spain, and how most tellingly to analyse these differing but related modes.

According to my interlocutors, the first reaction to the referendum result by many British residents who voted 'Remain' was numbness. They explained that soon morphed into an extended, emotional process they explicitly compare to grieving. Their 'bereavement', which could last three weeks, was one mixed with worry, fear for the future, and 'severe depression'. In some places, these sentiments were heightened by the sardonic reaction of their Spanish friends. One said the day after the result village acquaintance would approach him in the street with a condescending smile, 'But Peter, you are still here! When are you going home?' Another said that on the same day the local mayor, a friend, knocked on his door to say, with a smirk, and in English, 'Bye, bye, Jim. Bye, bye.' Though 
sardonicism was not universal, no one I spoke with or knew reported sympathetic interest from their Spanish neighbours. These deeply upset residents shared their grave concerns and anger with similarly afflicted friends and acquaintance, both face-to-face and digitally. Some of the more energetic agreed to organise, but exactly into what they were not immediately sure.

The campaigning groups began to emerge, first between friends, next by word-ofmouth, then by email and the creation of online-mediated groups. It is important to emphasize from the beginning how much campaigners' activities are enabled, indeed boosted by social media, especially Facebook and Twitter. For this struggle is the first UKcentred, transnational popular political protest against the actions of the governing party in Britain, and it is so effective and well-organised because, partially but crucially, much of its activity takes place online. Most of these groups have at least one, if not several IT-savvy members within their inner circle; the websites of many are sophisticated and kept rigorously up-to-date; their Facebook pages are equally active fora for disseminating information and exchanging opinions. Given the feelings generated by the referendum, these fora may fulfil further functions. The press has widely reported that Brexit has divided families and endangered friendships (e.g. Frostrup 2016; Lindsey 2016; Pearson 2016; Harris 2017; Lyons 2017; Marsh 2017; Delingpole 2018). A Remain in France Together (RIFT) spokesperson stated, at the meeting in June 2017 in Perigueux my co-worker and I organised for the campaign groups, that some members were spending several hours a day on their Facebook page: he explained that it provides 'a safe place for them to let off steam about Brexit', as well as offering them 'a lifeline and measure of understanding they don't get with their families'.

Many groups grew remarkably quickly, primarily thanks to the Internet. For example, the week after the 2016 referendum some like-minded British migrants in Almerla, southeast Spain, met and agreed to canvas support for an organised group, which they dubbed Europats. Within six weeks, its organisers had developed a database of about a thousand email addresses; by June $2017,6,000$. Here, IT is making the velocity of interaction a social factor of its own, its temporal affordances enabling choice of political trajectory (MacClancy n.d.)

Some groups are nationally framed, e.g. Bremain in Spain, RIFT. As online-oriented communities, however, campaign groups are not necessarily confined to national boundaries. The constitution of some is explicitly transnational, aiming to represent British migrants in more than one country or throughout the EU, e.g. Brexpats-Hear Our Voice. Some, mindful that the EU wishes to negotiate the position of EU residents in the UK, seek to act for both Britons abroad and EU migrants in Britain, e.g. Expat Citizen Rights in Europe (ECREU), Eurocitizens. In early 2017 eleven groups formed a broad EU-wide coalition: British In Europe, with c.30,000 members, by June 2017. Most put the particular priorities of their individual groups temporarily aside for the sake of exploiting the power of agglomeration. 
Representatives, one from each group, teleconference fortnightly to share news and information, debate present issues, finesse priorities, promote events and campaigns, and agree on pressing actions; sub-groups, working on specific tasks, meet online more often, then disseminate information to the membership. The coalition is so successful that some groups now question their independent existence.

Leaders of some of the Spanish-based groups accept the majority of their membership is regionally confined; this can lead to recruitment flatlining. Leaders of geographically wider groups see the resulting organisational diversity as a richness, not a weakness: the more regionally-oriented groups can maintain activity at the local level; the wider groups can invest more energy in broader initiatives. A more local, Hispanocentric group, such as Europats, tends to focus on working with their local town-halls, municipal commonwealths (mancomunidades), and deputies to the national Cortes, seeking and often receiving support from these different levels for their claims, as well as contacting British MPs.

The pre-Brexit political experience of the activists resident in Spain is mixed. Some had none previously; one leader of a major group stated that current affairs had not interested her at all until the referendum. However, unlike the councillors, several leading anti-Brexiters do have British-based experience of activist campaigning. Many of them had careers in public service: the NHS, the police, municipal administration; some have received honours for their distinguished public service. But remarkably few of them had participated beforehand in campaigns in Spain. Thus for British residents, standing for the town-council and setting up at least major Brexit campaign groups appear to be relatively separate trajectories, so far. This difference is not absolute: a sole British town-councillor did attend the Elche meeting my co-worker and I organised in April 2017: she had recently got her town-hall to declare concern for its British residents, and had then personally handed the declaration to the Prime Minister of Spain.

Whatever their organisers' level of experience, their concerted actions appear to achieve results, keeping their concerns high up on the Brexit agenda of HMG. Their actions, to date, include: block-emailing the Department for Exiting the European Union (DexEU); issuing an Alternative White Paper on the EU (Notification of Withdrawal) Bill; lobbying MPs, Lords, and MEPs; maintaining contacts with embassies, consulates, and academics (such as myself); co-launching a European Citizens' Initiative to guarantee EU passports for postBrexit Brits; co-organising, participating in, and speaking at anti-Brexit demonstrations in London, Madrid, and other cities; January 2017, being accepted as representatives of British migrants and transmitting their concerns to the House of Commons Select Committee for Exiting the EU. In the world of politics, where statements can be made for a plethora of reasons, and interpreted in an equally diverse manner, it can be difficult to provide definitive proof, if that is so desired, that the groups have produced change. Also, a certain scepticism is necessary when assessing the self-made claims of groups about their 
effectiveness. However, the groups can adduce evidence which indicates strongly that their words do have weight: for instance, information supplied by Bremain in Spain was re-stated in the House of Commons, and one of their lobbyists was quoted in debate in the chamber. In March 2017 the coalition was pleased the report for the Committee on Exiting the EU accepted several of the migrants' concerns. Further, as one Bremain in Spain representative claimed, 'We have considerably influenced the content of the EU proposals on citizens' rights - it is evident every time we submit new information, as the proposals have changed before our eyes, sometimes even using the exact same language' (Bremain representative, email, 20 iii 2018).viii

Though many group representatives have previous campaigning experience, they were surprised at what they see as the cynicism, duplicity, and exploitation they are experiencing from governing politicians. In early 2017 David Jones, Minister of State at DeExEU, told the House of Commons, 'We have engaged a range of stakeholders, including migrant groups, to ensure we understand the priorities of UK nationals living in EU countries'. Since none recalled speaking to Jones, campaigners responded by block-emailing DeExEU with their concerns. One activist said MPs had told representatives of her group, to their surprise, 'You've moved away. Why should we bother?' Also, the governing Conservative party had told them that a 'Votes-for-life' Bill, guaranteeing the electoral rights of British migrants, would go through, but then failed to ensure that it did. In April 2017, in conference-call meetings with British residents in Spain, held in the British Embassy, Madrid, and the British Consulate, Alicante, Jones and other HMG spokespersons emphasized they wished the campaign groups to make repeated representations to the Spanish Government to support their demands. At meeting's end, the spokespersons thanked group representatives 'for telling us things and ideas we'd not have thought of' (Interview with Bremain representative, April 2017). One campaign leader saw this as DexEU relying on the groups for information, and wanting them to do its work for Ministry ends: to prepare the Spanish Government before HMG began negotiating seriously on the issues. On this interpretation, HMG assisted in empowering activists: recognising the worth of their interstitial position and asking them to intercede on their behalf. According to this logic, HMG acknowledged its own relative weakness and created a further space in this openended process, another one within which the activists could play a political role. The British Consul, Alicante, is keen I emphasize this is a campaigner's interpretation, not that of the Consulate.

These groups direct their efforts at politicians, but also run press offices, to correct misrepresentation of the migrant populations: most English media tend to stereotype residents in Spain as jingoistic retirees, though only c.35\% of British residents there are pensioners; the great majority of the rest hold down some work.ix Similarly, the campaign group Britain in Europe works to counter continental simplifications with a website photo gallery underlining the diversity of British migrants: workers from diverse sectors, 
schoolchildren, single parents, entrepreneurs, pensioners, early retirees, families, students. Though most are lifestyle migrants, no one sub-group dominates.x

In sum, the anti-Brexit groups formed and grew very fast, by activists who had little experience of campaigning in Spain. The Internet enabled the level of organisation and speed of political response of the groups, and they appear to having an effect, and regard themselves as having effects, in their dealings with EU bodies. In the following two sections, I compare the discourse of the town-councillors and the campaigners, and then investigate how well application of contemporary practice theory and Isin's approach can enlighten our understanding of the activities of both groups.

\section{A language and practice of morality, or of rights?}

The town-councillors attempt to justify their actions and aims in terms of what they might class an everyday ethics. They propound a morality whose appeal and persuasive power is based on an implicit claim: their ethics is so commonsensical, so universally acceptable that no further grounds of justification are necessary; hence their unquestioned concern to denounce corruption, nepotism, and other municipal abuse. They utilise an 'unofficial' ideology, one not subject to the same stringent criteria of internal coherence as the carefully thought-through social theory of professional party politicians. For councillors, unexamined notions of fairness and justice are good-enough yardsticks; popularly accepted modes of evaluating ideas and behaviours whose deployment should prove relatively uncontroversial. In effect, they argue what kind of municipal candidate could have any chance of electoral success if they dared to openly oppose the upholding of fairness and justice?

In contrast the activists, though also migrant politicos, operate in a very different terrain. Like the town-councillors, they have to bend to administrative procedure. Unlike them, they are entering much more extensive, amorphous, complex, multicultural spaces where appeals to a quotidian, vernacular morality, perhaps one more posited than tightly integrated or logically structured, hold little chance of sway. Instead, in the hope of achieving their aims, the contexts they are entering, and helping to re-fashion, force them to adopt a rights-based discourse.

A further contrast is their attitude to 'Europe'. Very few councillors referred to it as a relevant category. The topic was not even raised in my 2015 interviews: councillors' horizons were mainly limited to the local, a bit to the regional, and rarely to the national; anything beyond seemed below their skyline. Studies of British councillors in southwest France in the mid-2000s and the early 2010s report the same (Drake and Collard 2008: 227, Ferbrache and Yarwood 2015: 79). In contrast, Janoschka, who fieldworked in the 2000s, found 'a strategic use' of European identity by foreign councillors as a foil to comment on 
local politics (Janoschka 2010: 710). But this was most likely a consequence of the contemporary anti-expropriation campaign in his fieldsite, where protestors' concerted, repeated appeals to the EU were central to achieving their aims. Unlike the 'Euro-shy' councillors Collard, Ferbrache and I interviewed, anti-Brexit campaigners, by definition, make the EU and 'Europe' key frames within which they act. Their discourse would be incoherent without them.

The main priorities of the campaign groups are: access to healthcare services; securing of pensions; unfettered travel; home ownership; exchange rates; votes for life; inheritance rules; choice of country of retirement. They couch their claims in a language of rights and citizenship. For instance, ECREU calls itself 'a lobby and self-help group set up to ensure that the issue of individual rights are foremost in the minds of those negotiating our future within the EU'; one of its two key aims is 'to protect the best interests of UK citizens living in the EU'. Similarly, the Governing Principle of the Alternative White Paper is: 'UK citizens currently resident in the EU and EU citizens currently resident in the UK should be expressly treated as continuing to have the same rights as they had before Brexit' (Golding and Morgan 2017: 2). All the fundamental statements of the other campaign groups mirror ECREU's: there is no appeal to a common morality. Rather, as still members of the EU, they believe they have the right to claim and secure rights, and they argue within the terms of that discourse. In other words, the town-councillors wish to traverse a primarily ethical terrain to reach a just end, while the campaigners triangulate their course along the contours of rights-based discourse, i.e. along social, political and legal lines.

Activists couch the possession of rights within a broad concept of citizenship. One highly innovative dimension of their campaign is that they are attempting to help generate a new style of citizenship. Traditionally, citizenship was defined within the frame of the nation-state (Isin and Turner 2002). The citizens of a country, and there were no citizens without countries, were those born and brought up within the borders of that country. This was the general rule, though of course there were always some exceptions: e.g. those born abroad to nationals working on government service or for colonialist end. This general assumption was so well-rooted and accepted that it usually went unquestioned. Thus citizenship and nationality could mesh unproblematically, indeed almost invisibly.

The sustained development of the EU questioned that hitherto-assumed categorical rationality (Lister 2008). As it struggled toward the creation of a supra-national entity, the link between citizenship and nationality was logically disrupted, and with it the assumed association of rights with nationality. For instance, Britons disgruntled about an aspect of governance became able, as EU members, to challenge the sovereignty of their own nationstate by appealing to a novel body: the European Court of Human Rights. Both the Court and the European Convention of Human Rights, which it upholds, are without precedent in English legal history and, as such, a particular bugbear for pro-Brexiteers. But logical disruption does not entail dissolution: though Eurocrats might wish to give further 
substance to notions of European citizenship, fiscal practice and actuarial processes across the EU still 'presume a more or less static and bounded populace'; the fluid lives of migrants are confounded by fixed laws, ones in need of change (Ackers and Dwyer 2004: 463). The sum result of these and related EU-phenomena is that EU citizenship remains a shifting, contested notion; it is that open contestation which activists exploit, to create a dynamic space in which to develop their case. Indeed the legal theorist Patricia Mindus argues the best possibility of decoupling EU citizenship from its member-state counterparts, to the benefit of post-Brexit Brits abroad, is via a mass citizens' initiative (Mindus 2017: 92-94). If this be right, the activists' power to set the agenda and steer the refiguring of EU citizenship is potentially all the greater.

The activists are not working towards 'shadow-nationality' (Ronkainen 2011), a 'citizenship of convenience', where migrants 'cherry-pick their rights and strategically evade certain' territorially-defined duties' (Ferbrache and Yarwood 2015: 82), or 'reciprocal rights', beloved of social contract theorists, which attend to both the rights of citizens and those of states; nor, unlike the claimants studied by Isin, are they usually claiming 'a right. . to a liveable life when no such prior authorisation exists' (Isin 2013: 32). Instead, they are advancing a maximalist position, seeking to pressure EU bodies and those of relevant member-states to guarantee as many of the rights they at present enjoy, and to guarantee certain rights they do not at present enjoy, e.g. votes for life. (Britons who reside abroad for more than fifteen years lose their right to vote in UK national elections.) At the same time, some have pursued an alternative strategy: organising a petition, signed so far by over 21,000 , calling on the Spanish Government to grant dual nationality, a status which does not yet exist in Spain, for Britons resident in the country for over ten years.xi In sum, as occurred in Italy, though there because of organised protest by underprivileged migrants (Oliveri 2012), activists can significantly contribute to open the boundaries of citizenship.

Why did these incomers become politically active in the first place? Again, it is hard to generalise about the councillors. Four said local politicians had invited them to stand; they were seen as vote-catchers, attracting the migrant electorate to the party ticket. Two said acquaintances had urged them to stand. Almost all had previously worked in sociallyoriented organisations. Almost all mentioned that office-holding had integrated them better into native society; indeed several underlined they now had many more Spanish friends than English ones. Perhaps the key difference between them and the campaigners is that their initiatives have tended to be far more individual in style, and rarely stretched beyond municipal boundaries. In contrast, from their very beginning, the campaigners have been united in their upset and anger. They share their indignation, and turn it to productive end, ultimately to a continental boundary.

Activists' behaviour may be regarded as a means for them to regain an integral sense of self. If identity is today considered socially and personally central yet dynamic and contested, then the June 2016 referendum is a rare instance of what some activists class the 
'theft' of their identity: a label they possess and value has been 'stolen' from them. As a member of the Bremain in Spain Council stated to me, 'I was raised in Britain, worked in Germany, have lived in Spain for twelve years, and am going to Italy soon to marry my Italian boyfriend, where we will live. I feel very, very European. How can people take that from me?' Others complain they are being involuntarily re-classed from EU-residents to migrants, while the campaign groups reject openly their subaltern status and proclaim their actorhood by their much-repeated slogan, 'We are not bargaining chips!' Turning activist can be seen as a way to publicly declare opposition to this categorical dispossession, and to retain a sense of the snatched identity. Theodossopoulos, studying the Greek financial crisis, saw locals' identification with communal indignation as an attempt to explain, and so subdue the crisis (Theodossopoulos 2013: 208). Something similar is occurring in Spain. For both Greeks hobbled by austerity measures and UK migrants fighting Brexit, their voiced indignation is empowering. Of course this empowerment is not exclusive to the activists: PIPN's Facebook page declares its morally-grounded desire 'to make meaningful steps towards political empowerment'. It is difficult to avoid adding that some might also see prominent activism both as self-therapy, and as a means to create a publicly virtuous position for oneself, though denigrated by some non-activists as 'keyboard warriors' (activists whose activity does not venture beyond their computer) or 'snowflakes' (a delicate item that can only endure in narrowly defined conditions).

\section{The habitus of town-halls, the enactment of Brexit}

Bourdieu's approach, born out of his study of Kabyle rural society in 1950s Algeria (Bourdieu 1977), and modern versions of practice theory fit cases where change is gradual or modulated. They dovetail with an analysis of maintained, but developing municipal practice, where foreign residents exploit their social capital to win seats, and develop their cultural capital by learning to understand Valencian.

In Spanish town-halls, the routines are humdrum, though the practices may be lively. Their habitus has long accommodated fiery debate, petty tyrants, secession, nepotism, clientelism, switching parties, and other forms of ill-regarded but much-pursued municipal behaviour.xii The election of British residents has not altered significantly this habitus; indeed some have been accused of corruption themselves. British councillors may propose and see implemented innovative initiatives, but this is a long-established part of municipal government. Native councillors may work to restrict their effectiveness, to limit their activities, and to fragment their power blocs but, again, this is in the nature of timehonoured interfactional competition: i.e., the elected foreigners have both learnt to adapt, and to adapt to, municipal ways. The habitus evolves; it is not questioned fundamentally. 
Janoschka, who fieldworked during the mid-2000s expropriation campaign, asked whether the 'temporarily radicalized habitus' would turn into a permanently reconstituted one (Janoschka 2011: 229). None of the British I spent time with mentioned this campaign; when asked, most confessed ignorance or very mild, distanced knowledge of it. This suggests foreign residents' sense of activist history is shallow: no incomer councillors have yet retained their posts for a third term, while many migrants return home on widowhood or impending infirmity. My field data also suggest the mid-2000s radicalisation of habitus was indeed temporary; it did not extend beyond the successful achievement of the campaign's aims. The organisation formed by the protestors achieved its aims and ended. Its lessons have seemingly been forgotten.

Until 1999 it was commonly accepted non-national residents were not to criticize Spanish politics publicly. What the arrival of the British migrants to office and their performance once there has changed is participants' notions of electoral and political rights, and the link of those with ideas of nationality. None of the councillors I interviewed raised these points; it was not part of their vocabulary. But once the Spanish Government had accepted that non-Spanish EU-member state residents could vote and stand in municipal elections, Britons and other migrants became able to exercise hitherto-unknown rights: to become political participants in a European country in which they had not been born or raised, but in which they resided. The bond between nationality and the ability to voice local political opinion had been broken. For the first time, non-Spanish residents could stand on soap-boxes or rise in town-hall meetings, and publicly damn the conduct of local Spanish representatives without being accused of meddling in other people's business: from 1999, it was their business. This was the key, perhaps revolutionary change: in terms of practice theory, it was more a change of field than a radicalisation of habitus. In other words, the verbal strategy or disposition was not new; habitus did not change, but those who could practise it had altered: the field had been expanded to include migrant residents. Legitimate political activity within an EU country was no longer dependent on the actor being a citizen of that country.

In contrast Isin's approach is specifically targeted at cases where alteration is central. It focuses on examples where radical challenge to the status quo and an open-ended process are at the core of relevant activities. It fits with an analysis of an innovative, everdeveloping campaign in a novel situation. To use Isin's vocabulary, the 1999 change enabled foreign residents to enact EU citizenship in a novel manner, but within a stable context. The Brexit process is different. Even if the notion of habitus could be stretched productively to incorporate its multiplex dimensions, which I doubt, it would still fail to grasp in an adequate manner what makes Brexit unusual. For this is a future-oriented, geographically diverse process where only the general end is clear: British departure from the EU. Exactly how, on what grounds, in what terms withdrawal occurs is being decided now in a much contested negotiation, where even the nature of the participants, what they can perform, and what they can achieve is being progressively defined. 
The sustained actions of the activists, via social media, in face-to-face meetings, in the streets, appears to be having a noticeable steer on the course of these debates and negotiations. Bottom-up agitators, they are challenging top-down arrangements, exposing the otherwise seemingly monolithic EU polity as in reality a complex European institutional assemblage, a variety of different stages where they can stake their claims and make their voices heard, as both securers and claimants of rights, who are operating provincially, nationally, internationally. They are imaginatively navigating a range of different sites and scales in what for many politicians were unexpected, unauthorised, and somewhat unconventional ways. They confront 'dominant understandings of citizenship as membership in a contained polity' and in so doing demonstrate its dynamic and fluid nature, its ongoing process of construction (Isin and Saward 2013: 15). At the same time, to deploy Isin's taxa, the activists' acts turn themselves from residents into performative actors, whose events, e.g. demonstrations, appeals, and claims, 'create possibilities of acting in certain ways not previously possible' (Isin 2013: 23).

Isin's approach can be re-assessed, however, in at least two aspects. First, Isin wants to emphasize the fluid nature of the dynamic processes he wishes to see studied. He also desires to escape the disabling dimensions of former theories by creating a novel analytical vocabulary. Yet his choice of terms is too static, emphasizing 'acts' rather than process, so threatening to unravel a central thread of his approach. One could counterargue this is a necessary consequence of linguistic structure: every sentence has to have a noun. But isolating concentrated though brief stretches of processes as 'acts' is always open to charges of arbitrary delimitation and threatens to cramp the processual dimensions Isin is so keen to develop. Perhaps we should concentrate on processes of enacting rather than moments of 'acts'.

Second, Isin's approach is insufficiently self-reflexive. The activists he studies participate in a rolling context, of which they and we their scholars are a part. Yet the present style of Isin's theory ignores the integral role of a researcher as a participant in the process he/she is studying: in the context of Brexit, that role may be central both because of the creative, open-ended nature of activism here, and because of internet activity. Two examples: first, at a Brexit seminar held at Southampton University in March 2017, a doctoral student studying one activist campaign group discussed his rapid incorporation into its inner circle.xiii When asked if he was now more an activist than an analyst, he replied, 'I analyse data, I make comments on positions taken, I do not suggest strategy.' Whether he can retain that distinction as the process develops remains open. Second, after I gave lunch at an Oxford college to a leader of another group, and invited other representatives to our Elche gathering in April 2017, accounts of both meetings soon went up on their websites, as they did on our project webpages. Ferbrache and I had hoped our webpages would become an integratory site of their own, bringing together otherwise disparate groups. In fact the meeting itself, more than the website, fulfilled that role. In this sense, activist and analyst both play parallel but interactive games for similar justificatory ends, though of course the 
effect of each is wildly different. Either way, the point remains: we should not prematurely exclude ourselves from the exploratory, unfolding processes we study, even if our own role may be minor.

$+$

The theories anthropologists choose steer the ways we analyse our data, and vice versa. Contemporary practice theory accommodates to dimensions of change, but still amidst a relatively enduring habitus. The work of most practitioners thus leans towards closure: the establishment of new habits. Isinians take an opposing tack, deliberately, chasing change and its kaleidoscopic variations, patterns developing with each turn. They select the openended and exploratory, tracking process over structure, the contested and the provisional over the lasting. Though they might work at different scales and have different limitations, practice theorists research how people cope with change; Isinians, how they produce it.

Anthropologists of lifestyle migration have tended to neglect its potential political dimensions. I have tried to redress that imbalance, analysing two overlapping examples where lifestyle migrants behave politically. British councillors in Spain have struggled, sometimes successfully, to alter the course of municipal policy and style while simultaneously adapting to many of its regulations. But their domination by native councillors restricts their innovatory range. There are few such constraints in Brexit. Campaigners are as creative as they can, and can see themselves as empowered by HMG. They are protagonists, not bit-part actors, fighting to mould the continuing process of which they are a part.

The activity of both the councillors and the anti-Brexit campaigners demonstrate the dynamic nature of citizenship, broadly conceived, today. Study of their behaviour furthers the anthropology of modern citizenship. The migrant councillors have exploited the EUdecoupling of political activity and a nationally grounded citizenship, in the process fleshing out what constitutes an emerging, novel form of municipal citizenship. More recently, campaigners are fighting to secure novel arrangements of EU-citizenship, pressuring governments to adjust. These protestors create an affective political economy, bound together in an empowering state of righteous indignation. In the above, I have analysed to date the unfolding of these twin processes. What forms of citizenship are finally accorded, how effective or enduring a motor indignation will be are two concerns campaigners continue to address in the unprescribed, future-oriented process that is Brexit. 


\section{Acknowledgements}

ESRC-IAA grant CORYSL00-AE01.11 funded the Elche and Pergiuex meetings, for which Fiona Ferbrache and I are thankful. Also, my gratitude to the British consular staff, Alicante, particularly Sarah-Jane Morris, the British Consul; to all those I spoke with, who generously gave up their time; to Mikko Kuisma, Fiona Ferbrache, and Irmak Karademir Hazir for reading drafts of this paper; and to three anonymous JRAI reviewers, for their questions and suggestions; and especially to Elizabeth Hallam for her painstaking commentaries on the successive versions of this paper. 


\section{Bibliography}

Ackers, L., and Dwyer, P. 2004 'Fixed laws, fluid lives: the citizenship status of postretirement migrants in the European Union', Ageing and society, 24(3): 41-75

Bakewell, 0. 2010 'Some reflections on structure and agency in migration theory', Journal of ethnic and migration studies, 36(10): 1689-1708

Beigel, F. 2009 '"Sur les Tabous Intellectuels": Bourdieu and academic dependence', Sociologica, May-December, 2-3. Available at https://www.rivisteweb.it/doi/10.2383/31370 (accessed $31 \vee 17$ )

Benson, M. 2011 The British in rural France. Lifestyle migration and the search for a better way of life. Manchester: University of Manchester Press

Benson, M., and O'Reilly, K. 2009a 'Migration and the search for a better way of life: a critical exploration of lifestyle migration', The sociological review 57(4): 608-625

--- (eds.) 2009b Lifestyle migration. Expectations, aspirations, and experiences. London: Routledge

Benson, M., and Osbaldiston, N. (eds.) 2014 Understanding lifestyle migration. Theoretical approaches to migration and the quest for a better way of life. London: Palgrave Macmillan

Bourdieu, P. 1977 Outline of a theory of practice. Cambridge: CUP

---1990 The logic of practice. Stanford, CA: Stanford University Press

---2005 'Habitus', in J.Hillier \& E.Rookby (eds.), Habitus: a sense of place, 2nd ed. Aldershot: Ashgate, 43-49

Bousiou, P, 2008 The nomads of Mykonos. Performing liminalities in a 'queer' space. Oxford: Berghahn

Collinson, P.2015 'Environmental attitudes, community development, and local politics in Ireland', in J.MacClancy (ed.), Alternative countrysides. Anthropological approaches to rural Western Europe today. Manchester: University of Manchester Press, 46-60

Croucher, S. 2009 'Migrants of privilege: the political transnationalism of Americans in Mexico', Identities: global studies in culture and power, 16(4): 463-491

Daloz, J-P. 2013 Rethinking social distinction. London: Palgrave Macmillan

Delingpole, James 2018 'Even being pro-Trump didn't lose me so many friends as being proBrexit', The Spectator, 24 February. Available at https://www.spectator.co.uk/2018/02/even-being-pro-trump-didnt-lose-me-as-manyfriends-as-being-pro-brexit/ (accessed 19 xi 18) 
Drake, H., and Collard, S. 2008 'A case study of intra-EU migration: 20 years of "Brits" in the Pays d'Auge, Normandy, France', French Politics, September, 6(3): 214-233

Engel, M. 2016 "'I don't want to have to go back to the UK with nothing"', The Guardian, 28 May: 31. Available at https://www.theguardian.com/politics/2016/may/27/brexit-threat-tospains-secret-little-britain (accessed 19 xi 18)

Edwards, J., Haugerud, A., and Parikh, S. 2017 'Introduction: the Brexit referendum and the Trump election', American Ethnologist, Forum section, April, 44(2): 195-200

Ferbrache, F., and Yarwood, R.2015 'Britons abroad or European citizens? The negotiation of (trans)national space and citizenship by British migrants in France', Geoforum, 62: 73-83

Franquesa, J. 2016 'Dignity and indignation: bridging morality and political economy in contemporary Spain', Dialectical anthropology, 40(2): 69-86

Frostrup, Mariella 2016 'My partner and I are at breaking point over Brexit', The Guardian, 31 July. Available at https://www.theguardian.com/lifeandstyle/2016/jul/31/my-partnerand-i-are-at-breaking-point-over-brexit (accessed 19 xi 18)

Gemperle, M.I 2009 'The double character of the German "Bourdieu". On the twofold use of Pierre Bourdieu's work in the German-speaking social sciences', Sociologica, January-April, 1. Available at https://www.rivisteweb.it/doi/10.2383/31370 (accessed 31 v 17)

Golding, J., and Morgan, J. 2017 UK Citizens in Europe: Towards an Alternative White Paper on the European Union (Notification of Withdrawal) Bill. Available at

https://britishineurope.org/wpcontent/uploads/2017/02/alternative white paper presented by uk citizens in europe. pdf (accessed $19 \times$ i 18)

Govan, F. 2008 'British expat becomes "accidental” mayor of Costa Blanca', The Daily Telegraph, 30 October. Available at http://www.telegraph.co.uk/news/worldnews/europe/spain/3286974/British-expatbecomes-accidental-mayor-of-Costa-Blanca.html (accessed $30 \vee 17$ )

Green, S. (ed.) 2016 'Brexit referendum: first reactions from anthropology', Social Anthropology, Forum section, November, 4: 478-502

Harris, C. 2017 'How break-ups and lost friendships have been Brexit's hidden casualty', Euronews, 23 June. Available at https://www.euronews.com/2017/06/23/how-break-upsand-lost-friendships-have-been-the-hidden-casualty-of-brexit (accessed 19 xi 18)

Heiberg, M. 1989 The making of the Basque nation. Cambridge: CUP 
Huete, R., and Mantecón, A. 2012 'La participación política de los residents británicos y alemanes en España: el caso de San Miguel de Salinas, Alicante', Revista de geografía Norte Grande, 51: 81-93. Available at http://www.redalyc.org/articulo.oa?id=30023283009 (accessed $30 \vee 17$ )

Isin, E, 2008 'Theorizing acts of citizenship', in E.Isin \& G.M.Nielsen (eds.) Acts of citizenship. Chicago: University of Chicago Press, 15-43

---2009 'Citizenship in flux: the figure of the activist citizen', Subjectivity, 29: 367-388

---2012 Citizens without frontiers. London: Bloomsbury

---2013 'Claiming European citizenship', in E.Isin \& M.Saward (eds.) Enacting European citizenship. Oxford: OUP, 19-46

Isin, E., and Saward, M. 2013 'Questions of European citizenship', in E.Isin \& M.Saward (eds.) Enacting European citizenship. Oxford: OUP, 1-18

Isin, E., and Turner, B. 2002 'Citizenship studies: an introduction', in E.Isin \& B.Turner (eds.) Handbook of citizenship studies. London: Sage, 1-10

Janoschka, M. 2009 Konstruktion Europaischer Identitaten in Raumlich-Politischen Konflikten. Weisbaden: Franz Steiner Verlag

--2010 ‘Prácticas de ciudadanía europea. El uso estratégico de las identidades en la participación política de los inmigrantes comunitarios', Arbor, CLXXXVI(744): 705-719

---2011 'Habitus and radical reflexivity: a conceptual approach to study political articulations of lifestyle- and tourism-related mobilities', Journal of Policy Research in Tourism, Leisure \& Events 3(3), November: 224-236

Janoschka, M., and Durán, R. 2014 'Lifestyle migrants in Spain. Contested realities of political representation', in M.Janoschka \& H.Haas (eds.), Contested spatialities, lifestyle migration, and residential tourism. London: Routledge, 60-73

Jenkins, R. 1992 Pierre Bourdieu. London: Routledge

Kemp, C. 2010 'Building bridges between structure and agency: exploring the theoretical potential for a synthesis between habitus and reflexivity', Essex graduate journal of sociology, 10: 149-157

Lawson, M. 2016 Identity, Ideology and Positioning in Discourses of Lifestyle Migration: The British in the Ariège. London: Palgrave

Lindsey, Duncan 2016 'The 20 stages of falling out with your friends over Brexit', Metro, 28 June. Available at https://metro.co.uk/2016/06/28/the-20-stages-of-falling-out-with-yourfacebook-friends-over-brexit-5971079/ (accessed 19 xi 18)

Lister, M. 2008 'Europeanization and migration: challenging the values of citizenship in Europe?', Citizenship studies, December, 12(6): 527-32 
Lyons, E. 2017 'I was a Left leave voter but now Brexit has turned politics into a bearpit', inews, 4 June. Available at https://inews.co.uk/opinion/politics-lord-flies-guess-good-mine/ (accessed 19 xi 18)

MacClancy, J. 2000 'The predictable failure of a European identity', in B.Axford, D.Berghahn, and N.Hewlett (eds.) Unity and diversity in the new Europe. Oxford: Peter Lang

---2015 'Fear and loving in the West of Ireland: the blows of County Clare', in J.MacClancy (ed.), Alternative countrysides. Anthropological approaches to rural Western Europe today. Manchester: University of Manchester Press, 143-68

---n.d. 'Barth and Brexit, on line, on target' in T.H.Eriksen (ed.), Ethnic Groups and Boundaries Today: A legacy of fifty years. London: Pluto (in process of publication)

Margetts, Helen, 2013 'The internet and democracy' in William Dutton (ed.) The Oxford handbook of internet studies. Oxford: Oxford University Press, 421-439

Marsh, Sarah 2017 'It's not EU. . .It's Brexit: the couples in turmoil after referendum result', The Guardian, 7 February. Available at https://www.theguardian.com/commentisfree/2017/feb/07/eu-brexit-couples-turmoilreferendum-relationship (accessed 19 xi 2018)

Mindus, P. 2017 European citizenship after Brexit: freedom of movement and rights of residence. London: Palgrave

Mouzelis, N. 2007 'Habitus and reflexivity; restructuring Bourdieu's theory of practice', Sociological research online, 12(6). Availabe at http://www.socresonline.org.uk/12/6/9.html (accessed 22 ii 18)

Oliver, C., and O’Reilly, K. 2010 'A Bourdieusian analysis of class and migration', Sociology 44(1): 49-66

Oliveri, F. 2012 'Migrants as activist citizens in Italy: understanding the new cycle of struggles', Citizenship studies, August, 16(5-6): 793-806

O’Reilly, K. 2012 International migration and social theory. Basingstoke: Palgrave Macmillan

Pearson, A. 2016 'The Brexit row is pulling friendships and families apart', The Daily Telegraph, 26 April. Available at https://www.telegraph.co.uk/opinion/2016/04/26/thebrexit-row-is-pulling-friendships-and-families-apart/ (accessed 19 xi 18)

Portes, A. 2010 'Migration and social change: some conceptual reflections', Journal of ethnic and migration studies, 36(10): 1537-1563

Postill, J. 2010 'Introduction: theorising media and practice', in B.Braüchler and Postill, J. (eds.) Theorising media and practice. Oxford: Berghahn, 1-26

---2012 'Digital politics and political engagement', in H.A.Horst \& D. Miller (eds.) Digital anthropology. Oxford: Berg, 165-184

Ronkainen, J. K. 2011 'Mononationals, hyphenationals, and shadow-nationals: multiple citizenship as practice', Citizenship studies, 15(2): 247-63 
Simó-Noguera, C-X., Herzog, B., Torres, F., Jabbaz, M., and Giner Monfort, J.2005 'Asociacionismo y población extranjera en la Comunidad Valenciana', Cuadernos electrónicos de filisofía de derecho, 12. Available at https://dialnet.unirioja.es/servlet/articulo;jsessionid=B26A7E50087437DE91D6796088E34C 01.dialnet02?codigo $=1307311$ (accessed $30 \vee 17)$

Sorge, A. 2009 'Hospitality, friendship and the outsider in Highland Sardinia', Journal of the society for the anthropology of Europe, Spring-Summer, 9(1): 4-12

Swartz, D. 2013 Symbolic power, politics and intellectuals. The political sociology of Pierre Bourdieu. Chicago: University of Chicago Press

Theodossopoulos, D. 2013 'Infuriated with the infuriated? Blaming tactics and discontent about the Greek financial crisis', Current anthropology, 54(2): 200-209

Tremlett, G. 2003 'Spanish fear for their way of life as Britons fight for power', The Guardian, 17 May. Available at https://www.theguardian.com/world/2003/may/17/spain.gilestremlett (accessed 12 v 17)

Valdés, Andrés 2015 'Británicos: el efecto "expat”. Así es la mentalidad que aísla a la mayor colonia de ingleses en un país no angloparlante', Información, 22 October. Available at https://www.diarioinformacion.com/suscriptor/dominical/2015/11/22/britanicos-efectoexpat-retiro-mister/1699374.html (accessed 19 xi 18)

Woodward, I., and Emmison, M. 2009 'The intellectual reception of Bourdiue in Australian social sciences and humanities,' Sociologica, May-December, 2-3. Available at https://www.rivisteweb.it/doi/10.2383/31370 (accessed 31 v 17)

i Out of 293 items on the Bibliography, Lifestyle Migration Hub, the only relevant references are Croucher 2009 and seven by Janoschka, http://www.uta.fi/yky/lifestylemigration/bibliography.html (accessed $30 \times 17$ )

ii I emailed a draft of this paper to most of those with whom I spoke, for their comments.

iii See, e.g., 'Valencia's land remains up for grabs', The Guardian, 23 iv 2006

iv For examples of the governing council putting obstacles in the way of not migrant political parties, but their civic associations, see Simó-Noguera et al. 2005: 90.

$\checkmark$ This statement is grounded on my own longterm knowledge of the provincial fieldsite. As far as I am aware, transfugismo (elected representatives switching party while in office) is not yet discussed in the academic literature. However a search for 'transfugas' on the webpage of the regional Alicantine daily newspaper Información produces tens of thousands of results (accessed 19 xi 18)

vi As for endnote 5, this statement is grounded on my fieldwork. A search for 'corrupción' on the webpage of Información produces over two million results (accessed 19 xi 18) vii Quotes from PIPN Facebook: https://www.facebook.com/PIPN-Partido-IndependientePor-Las-Nacionalidades-189052697809847/ (accessed 30 v 17) viii For further examples of digitally-enabled advocacy groups effecting real change, see Postill 2012, Margetts 2013. 
ix For examples of this media stereotype: Engel 2017;

https://www.theguardian.com/politics/video/2017/mar/16/british-expats-in-spain-countthe-costa-brexit-video (accessed 19 xi 18)

$\times$ http://www.britsineurope.com/ (accessed 25 v 2017)

xi https://www.change.org/p/dual-nationality-for-brits-who-have-resided-in-spain-for-morethan-10-years (accessed 20 iii 2018)

xii Evidence for this statement comes from my experience of rural fieldwork in Spain, which started in Navarre in 1984, and from discussions about this paper with two Spanish anthropologists based in Alicante province.

xiii 'The legacy of Brexit: mobility and citizenship in times of uncertainty', day-long seminar, ESRC Centre for Population Change, University of Southampton, 31 March 2017: attended by the author. 